The Review of Politics 83 (2021), 510-532.

(C) The Author(s), 2021. Published by Cambridge University Press on behalf of University of Notre Dame. This is an Open Access article, distributed under the terms of the Creative Commons Attribution licence (http://creativecommons.org/ licenses/by/4.0/), which permits unrestricted re-use, distribution, and reproduction in any medium, provided the original work is properly cited.

doi:10.1017/S0034670521000450

\title{
Trust and Distributive Justice in John Locke's Politics of Money
}

\section{Lee Ward}

\begin{abstract}
Modern commentators tend to view John Locke's theory of money either in terms of a process of naturalization placing currency completely beyond the realm of politics or as an effort to provide a moral foundation for a convention subject to epistemic instability. This study builds on the latter interpretation but offers an alternative to the standard view that Locke sought to remove monetary policy from the scope of ongoing political deliberation. While Locke emphasized the concept of trust necessary for the networks of credit and economic exchange, his account of money also prioritized prudential judgments and distinct discursive contexts, especially relating to distributive justice. Locke's economic tracts give reason to reconsider his putative role as founder of the "sound money" doctrine and shed light on aspects of his statecraft only partly visible in his more familiar political works.
\end{abstract}

John Locke's role in the development of early modern thinking about money is well established. For centuries, Locke's opposition to currency devaluation in England in the 1690s earned him the title of one of the founders of the "sound money" doctrine and defender of the institutions integral to the birth of capitalism during the Financial Revolution in England. ${ }^{1}$ This

Lee Ward is professor of political science in the Department of Political Science at Baylor University, One Bear Place \#97276, Waco, TX 76798-7276 USA (Lee_A_Ward@ baylor.edu).

The author would like to thank Monica Truschka, Ruth Abbey, and the anonymous reviewers of the Review of Politics for their comments on earlier versions of this article.

${ }^{1}$ See Thomas Babbington Macaulay, The Complete Works of Lord Macaulay in Eight Vols, ed. Lady Trevelyan (London: London, Green, 1866), 4:195-96; Albert Feavearyear, The Pound Sterling: A History of English Money (Oxford: Oxford University Press, 1931), 135; and Ming-Hsun Li, The Great Recoinage of 1696 to 1699 (London: Weidenfeld and Nicolson, 1963), vii. For the classic study of the Financial Revolution in England, see P. G. M. Dickson, The Financial Revolution in England: A Study of the Development of Public Credit 1688-1756 (New York: St. Martin's, 1967). 
narrative has proved remarkably resilient as most recent scholarship reaffirms this image of Locke, albeit with different emphases. However, there is no consensus among commentators about the political principles underlying Locke's theory of money. In the 1970s Joyce Appleby influentially argued that Locke inaugurated what would become the classical liberal idea of the naturalization of money, an account that would effectively remove considerations about currency "from the realm of politics." ${ }^{2}$ More recently, in her magisterial study of the invention of the modern idea of money in England, Christine Desan illuminates the revolutionary manner in which Locke "fetishized money as a matter of intrinsic metal content," in order to place currency not only "beyond control of the state," but "out of governance altogether."3

Another group of commentators reject this naturalist interpretation, and instead focus on the role that Locke's concern about epistemic instability in conventional intersubjective agreement played in his defense of unalterable currency denominations. ${ }^{4}$ In this account, Locke's monetary theory is animated by a conscious effort to provide the fragile mental construct that is money with a normative foundation to exclude currency from the range of issues included in the regular course of political debate. Arguably the most sophisticated version of this argument is Stefan Eich's recent offering in which he elegantly illustrates the political logic informing what he takes to be Locke's "depoliticization" of money. For Eich, Locke's solution to the problem of the "malleable conventionality" of money was to protect the "monetary contract" by sanctifying the fiat decision to link money to an initially arbitrary, but subsequently unalterable, quantity of silver. ${ }^{5}$ The unifying thread linking the otherwise opposed naturalist and conventionalist interpretations, including Eich's decisionist model, is the fundamental assumption that Locke sought to make considerations about money operate in a depoliticized manner outside the parameters of normal political deliberation.

The present study builds upon the conventionalist emphasis on Locke's epistemological concerns about the monetary compact. However, I add to the growing literature on Locke's theory of money by focusing on the problem of identifying Locke entirely with support for sanctifying currency,

\footnotetext{
${ }^{2}$ E.g., Joyce A. Appleby, “Locke, Liberalism and the Natural Law of Money,” Past $\mathcal{E}$ Present, no. 71 (May 1976): 69.

${ }^{3}$ Christine Desan, Making Money: Coin, Currency, and the Coming of Capitalism (Oxford: Oxford University Press, 2014), 16-17, 368.

${ }^{4}$ E.g., George Caffentzis, Clipped Coins, Abused Words, and Civil Government: John Locke's Philosophy of Money (New York: Autonomedia, 1989), 14; Daniel Carey, "John Locke's Philosophy of Money," in Money and Political Economy in the Enlightenment, ed. Daniel Carey (Oxford: Voltaire Foundation, 2014), 59-60; Douglas John Casson, Liberating Judgment: Fanatics, Skeptics, and John Locke's Politics of Probability (Princeton: Princeton University Press, 2011), 4-5, 254; and Hannah Dawson, Locke, Language and Early-Modern Philosophy (Cambridge: Cambridge University Press, 2007).

${ }^{5}$ Stefan Eich, "John Locke and the Politics of Monetary Depoliticization," Modern Intellectual History 17, no. 1 (2020): 4.
} 
a topic that has received little attention. ${ }^{6}$ In significant ways, my treatment of Locke's monetary theory follows that of Eich, whose focus on the issue of trust resembles the one advanced here. However, while I share Eich's emphasis on the political origins of money, I reject his claim that Locke believed establishing trust in money required accepting a fiat approach to monetary policy. Rather taking Locke's concern for the political ramifications of the money supply as a given, I pursue Locke's expectations for prudential judgment about the distributive consequences of monetary policy, as distinct from the question of the depoliticization of money.

Eich's argument for Locke's politics of monetary depoliticization is perhaps the most ingenious interpretation of Locke's monetary theory that recognizes its complexity but nonetheless still confirms the standard reading of Locke as the father of the "sound money" doctrine. ${ }^{7}$ I reject Locke's paternity of this concept. My interpretation of Locke's theory of money is not radically depoliticized, and indeed complements his broader idea of statecraft. My central claims are twofold. First, I will demonstrate that Locke did not seek to resolve the paradox of commodity money being both natural substance and contractual legal construct by eliminating or minimalizing either element of the compound relation. Rather, throughout his economic and political writings Locke maintained a complex balance between nature and convention in his treatment of money. ${ }^{8}$ Second, I challenge the common assumption about Locke's fears regarding the epistemic fragility of money, which rests on a misunderstanding of Locke's crucial concept of mixed modes, the epistemological category to which he assigns money. Even as subtle an analyst as Eich gets Locke backwards in this important respect by not recognizing that for Locke mixed modes are more intelligible than material substances. Thus I recontextualize Locke's theory of money in terms of his conception of practical reason, and contend that it is not the epistemic fragility of

${ }^{6}$ For an important exception, see Richard A. Kleer, “'The Ruin of Their Diana': Lowndes, Locke and the Bankers," History of Political Economy 36, no. 2 (2004): 533-56. But Kleer's approach is a historical and institutional focus on internal politics in the Treasury and parliamentary committees, rather than an examination of Locke's political theory.

${ }^{7}$ For recent studies that highlight Locke's role as the inspiration for "sound money" and the gold standard, see Eich, "Depoliticization," 2, and Daniel Carey, "John Locke, Money, and Credit," in Empire of Credit: The Financial Revolution in the British Atlantic World, 1688-1815, ed. Daniel Carey and Christopher J. Finlay (Dublin: Irish Academic Press, 2011), 26-29.

${ }^{8}$ Ince also recognizes the complex interplay of natural law "universals" and contingent "historical facts" in Locke's treatment of money in the Second Treatise, but does not extend this insight into analyzing Locke's monetary tracts. See Onur Olas Ince, "Enclosing in God's Name, Accumulating for Mankind: Money, Morality, and Accumulation in John Locke's Theory of Money," Review of Politics 73, no. 1 (Winter 2011): 29-33. Ince also, however, emphasizes a theological dimension in Locke's treatment of money that is, in my view, absent in his economic writings. 
normative concepts that drove Locke's reasoning about money, but rather his confidence about the conceptual durability and adaptability of complex legal and moral ideas. ${ }^{9}$

If, as Michael Zuckert observes, Locke is arguably the first important political philosopher "to define political economy as the central task of politics,"10 then it would seem natural to integrate Locke's argument about money with the broader conception of statecraft he calls the "great art of government."11 Locke's statecraft involves his commitment to the philosophical principle of individual natural rights combined with an approach to political and economic issues that prioritizes prudential judgments derived from practical reason over and against mechanistic theoretical propositions and sweeping universal laws of human behavior. ${ }^{12}$ My account of Locke's statecraft departs from Eich's decisionist model in which money originates in political judgment and then subsequently forecloses all future discursive possibilities about the currency. By contrast, I view Locke's conception of money as a mixture of natural and conventional elements amenable to periodic political deliberation about the distributive consequences of monetary policy. Thus, I propose that Locke's long association with the origins of a natural science of economics distorts his understanding of the relation of politics and economics and has obscured our sense of the complex normative features of Locke's theory of money in particular. ${ }^{13}$ By challenging the idea of Locke as the apostle of sound money, I hope to recover access to the range of theoretical perspectives that can inform political action concerning money offered in Locke's statecraft.

Before turning to Locke's monetary tracts, I provide some brief historical context for the English currency debates of the 1690s and then consider the role of money in Locke's more familiar political and philosophical writings. I then turn to examining in some detail Locke's argument for the "natural price of money" in Some Considerations of the Consequences of Lowering

${ }^{9}$ For Locke's conception of practical reason, see John Locke, Essay concerning Human Understanding, ed. Peter Nidditch (Oxford: Oxford University Press, 1975 [1690]), book 4 , chapter 21 , section 3 . Hereafter in notes and text $E$, followed by book, chapter, and section.

${ }^{10}$ Michael Zuckert, Natural Rights and the New Republicanism (Princeton: Princeton University Press, 1994), 272.

${ }^{11}$ John Locke, Second Treatise, section 42, in Two Treatises of Government, ed. Lee Ward (Indianapolis, IN: Hackett, 2016 [1690]). Hereafter in notes and text simply Treatise I or II, followed by section number.

${ }^{12}$ See Peter McNamara, Political Economy and Statesmanship: Smith, Hamilton and the Foundations of the Commercial Republic (DeKalb: Northern Illinois University Press, 1998), 5.

${ }^{13}$ E.g., William Letwin, The Origins of Scientific Economics: English Political Thought 1660-1776 (Westport, CT: Greenwood, 1963), 176; Karen Iverson Vaughn, John Locke, Economist and Social Scientist (Chicago: University of Chicago Press, 1980), 115; and Appleby, "Natural Law," 43. 
Interest and Raising the Value of Money (1691) and his case against currency devaluation in the Further Considerations concerning Raising the Value of Money (1695). I argue that Locke's economic writings present a theory of money that, rather than serving simply as a justification of sound money, combined normative and epistemological as well as distinctly political modes of prudential reasoning characteristic of Locke's statecraft as he sought to protect the moral foundations of community in a network of credit, trust, and social relations.

\section{Economic Controversies in 1690s England}

Some Considerations (1691) and Further Considerations (1695) are arguably the most policy-directed writings in Locke's oeuvre as they were composed in his official capacity as senior adviser to the Crown and member of the newly formed Board of Trade. ${ }^{14}$ Locke's fascination with interest rates dated back to April 1668 when a bill championed by Josiah Child, governor of the East India Company, proposed to lower the legal rate of interest from 6 percent to 4 percent. Child argued that this measure was necessary to restore English commercial supremacy over rival Dutch traders by imitating their policy of keeping interest rates low. Acting as principal secretary to Chancellor of the Exchequer Lord Shaftesbury, Locke wrote a memo opposing Child's proposal. Locke's position on interest rates prevailed in 1668, but the House of Commons reconsidered lowering rates again in 1690, and in response Locke revised and expanded his earlier memo into what became Some Considerations.

The Recoinage Controversy of 1695 had its roots in problems dating back decades in England. First, there was a shortage of silver in the country owing to the fact that for many years there had been a divergence in value between English silver shillings, on one hand, and the price of silver bullion, on the other, such that silver bullion came to exceed the value of silver coin markedly. This created an arbitrage opportunity to melt down English silver coins to convert into bullion for export to foreign markets in order to obtain a higher return either to buy gold guineas or to purchase more comparatively cheaper English silver coins. This produced a shortage of silver: England's main source of currency. The second problem was the phenomenon known as "clipping." Once again, the discrepancy between the price of silver coin and silver bullion was the culprit as it provided incentive to shave off or "clip" some of the silver coins in order to collect the shavings for melting down into valuable bullion. This meant that many, if not most, silver coins in circulation were in actuality lighter than the quantity of

\footnotetext{
${ }^{14}$ See Peter Laslett, "John Locke, the Great Recoinage, and the Origins of the Board of Trade: 1695-1698," William and Mary Quarterly 14, no. 3 (July 1957): 370-402.
} 
silver associated with the denomination. ${ }^{15}$ Clipping undermined public confidence in the real value of English coins and encouraged an international network of counterfeiters and smugglers. ${ }^{16}$

The need to reform the monetary system was given even greater urgency by the demands of the Nine Years War against France (1688-97) as by the summer of 1695 the government of William III scrambled to raise loans desperately required to supply unpaid troops in the field in Flanders. This crisis mercilessly exposed the inadequacy in the English currency and credit system. ${ }^{17}$ The Recoinage Debate must be understood in the context of the deliberate long-term policy to lay the foundation for what John Brewer identifies as the "fiscal-military state" that would propel Britain to imperial glory in the following century. ${ }^{18}$ But while there was broad agreement in 1695 about the need to address the problems in the English monetary system with some form of recoinage, there was no consensus on the proper course of legislative action. Two main alternatives emerged: (1) reminting and devaluation of all silver coins or (2) reminting them at the original valuation. The secretary of the treasury William Lowndes proposed a nominal devaluation of all silver currency by 20 percent with compensation provided for all those who surrender clipped coins. ${ }^{19}$ In Lowndes's view, devaluation was the best way to ensure that recoining did not result in a radical reduction in the supply of coins. On the other side, in Further Considerations Locke argued that all the silver coins in circulation should be reminted at the old weight and value with a more advanced technique called "milling" that promised to make clipping more difficult in the future. For Locke, the only way to restore the proper relation of bullion to coin, and public confidence in the currency, was by restoring the original value of the denomination. In order to understand Locke's reasoning during the controversies of this period, we need to consider aspects of his theory of money presented in his familiar philosophical and political works.

\section{A Philosophy of Money}

Interpretations of Locke's theory of money tend to revolve around the question whether he believed that money's value is natural or conventional. Some commentators argue that Locke "naturalizes" money by highlighting

\footnotetext{
${ }^{15}$ Patrick Kelly, introduction to The Clarendon Edition of the Works of John Locke: Locke on Money, vol. 1, ed. Patrick Kelly (Oxford: Oxford University Press, 1991), 20-21.

${ }^{16}$ Caffentzis, Clipped Coins, 21.

${ }^{17}$ Kelly, introduction to Locke on Money, 93; Li, Recoinage, 13; and Eich, “Depoliticization," 8.

${ }^{18}$ John Brewer, The Sinews of Power: War, Money and the English State, 1688-1783 (Cambridge, MA: Harvard University Press, 1988), 3.

${ }^{19}$ Kelly, introduction to Locke on Money, 20-24.
} 
its transformative character as the indispensable medium of exchange, ${ }^{20}$ while others emphasize the degree to which Locke believed its value to be determined originally by an arbitrary political fiat that has the same ultimate effect of putting money beyond future political control. ${ }^{21}$ Fully engaging questions about the naturalness of money requires considering the epistemology in Locke's Essay concerning Human Understanding, which famously cautioned against essentialist interpretations of the natural or intrinsic properties of substances such as gold and silver (E 2.23.2). Locke acknowledged that silver coin has a substantial reality as a material thing, that is, a metal of finite quantity. But he insisted that the name we give to a substance is simply based on a collection of observable simple ideas (E 2.23.3). In contrast to empirical observation governing understanding of substances, practical reason directed toward "the attainment of things good and useful" ( $E$ 4.21.3) is characterized by what Locke terms "mixed modes." Mixed modes are consciously constructed by a combination of simple ideas made "arbitrarily" by mind "without patterns, or reference to any real existence" (E 3.5.3), but rather by way of mental frameworks Locke calls "archetypes" (E 4.4.8). Mixed modes comprise the "greatest parts of the words made use of in Divinity, Ethics, Law and Politicks" (E 2.22.12). Locke concludes that the value of money is discernible precisely because it is a mixed mode derived from social convention and does not depend on knowledge of any naturally existing thing (E 2.22.1). But gold and silver are also, of course, durable and scarce material substances that supply the quantifiable, measurable, and portable objects that serve as the means for facilitating exchange. Commodity money is, then, both physical substance (silver and gold) and a moral mixed mode (valued currency).

Several commentators claim that Locke's reasoning with respect to money is driven by his deep anxiety about the inherent epistemic instability in mixed modes, especially as currency denominations are subject to the problem of disagreement about the meaning of language. ${ }^{22}$ However, this line of argument risks losing some of the original texture of Locke's epistemology, for he insisted in the Essay that substance is more difficult to understand than mixed modes. While simple ideas are the building blocks of knowledge, Locke claims that "our idea of substance" is "obscure, or none at all" with respect to thinking about body (E 2.23.15). So little does the concept of substance tell us about the intrinsic qualities of material reality that Locke compared the mysteries of physical body to the spiritual realm: "the idea of corporeal substance in Matter is as remote from our Conceptions, and

${ }^{20}$ E.g., Appleby, “Natural Law,” 69; Desan, Making Money, 372.

${ }^{21}$ E.g., Eich, "Depoliticization," 4; Carey, "Money and Credit," 28-29; John O'Brien, "John Locke, Desire, and the Epistemology of Money," British Journal for the History of Philosophy 15, no. 4 (2007): 692.

${ }^{22}$ Eich, "Depoliticization," 18; Casson, Judgment, 6; and Carey, "Philosophy of Money," 74-75. 
Apprehensions as that of Spiritual Substance" (E 2.23.5). The deep opacity in our knowledge of substance derives from the fact that the "real" essence of any substance is unavoidably elusive: "as to real essences of Substances, we only suppose their being without knowing what they are" (E 3.6.6). But Locke argues that mixed modes can be known precisely because they are entirely products of mind. Whereas natural philosophy can never reliably extend beyond the epistemological level of probability, morality is "amongst the sciences capable of demonstration" (E 4.3.18). ${ }^{23}$ Thus, while money understood as substance (metal) is ultimately ineluctable, money conceived as a "mixed mode" mental construct is comprehensible, normative, and in principle at least, instrumental to the promotion of human happiness.

While Locke recognized one of the great obstacles confronting human knowledge acquisition is the abuse of language and the difficulty to settle upon stable, publicly accepted definitions of terms (E 3.9-11), his political theory nonetheless presupposed a general human capacity to establish commodity currency exchange both in civil society and the seminal state of nature. In the philosophical anthropology underlying the state of nature in Locke's Second Treatise of Government he explicitly linked money with the law of nature that is "intelligible and plain" to any rational creature (II 12). Locke argues that in the early phase of social organization no one individual could realistically acquire property to the injury of anyone else because it was not yet true that "the desire of having more than men needed had altered the intrinsic value of things" (II 37). The alteration in the "intrinsic value of things" is produced when "by mutual consent" people agreed to place value on some "lasting thing" such as a "little piece of yellow metal" that could be used to exchange for the "truly useful, but perishable" supports of life (II 37, 47). In his discussion of land, which he calls the "chief matter of property," Locke contends that one acre of uncultivated land in precolonial America and another in monetarized England have "the same natural intrinsic value," and yet one benefits humankind much more owing to the productive capacities unleashed by money (II 32,43). But whereas "intrinsic" and "natural" value of land are tied to its productive capacity, these terms bear a different meaning with respect to money insofar as the natural and intrinsic value of money seems to be indelibly relational and context-specific. The "little piece of yellow metal" has monetary value because individuals agree to ascribe to it value.

While it is correct to take note of Locke's concern about the need to secure a stable definition of mixed modes, some commentators arguably exaggerate Locke's anxiety about the supposed fragility of the epistemic basis of the agreement about currency. ${ }^{24}$ Rather, Locke was so sanguine about the

${ }^{23}$ Of course, Locke famously demurred about his responsibility to provide such a demonstrative moral science (see $E \mathrm{xx}$ ).

${ }^{24}$ E.g., Casson, Judgment, 254; Eich, "Depoliticization," 18-19; and Dawson, Locke, Language, 286-89. 
semantic resilience of the concept of money that he held monetary agreements to be practically constitutive of international recognition of distinct legal borders. The importance of money to the process of community formation is undeniable as Locke insists that there are still parts of the world which lie "waste" because the inhabitants thereof have not "joined with the rest of mankind, in the consent of the use of their common money." Indeed, Locke concludes that claimable wasteland "can scarce happen amongst that part of mankind that have consented to the use of money" (II 45). ${ }^{25}$ Thus, the "common consent" to distinct borders is coterminous with the "common consent" (express or tacit) to the use of exchangeable "common money" in the form of silver and gold. Money, then, was not present in the original "great and natural community" of the human species, but rather only emerged in tandem with the "positive agreements" through which people "combine into smaller and divided associations" (II 128).

Locke declared that money is "a barren thing and produces nothing but by compact." ${ }^{26}$ Perhaps the chief moral implication of the invention of money is the "tacit and voluntary consent to inequality" by which "men have agreed to disproportionate and unequal possession of the earth" (II 50). As several commentators have noted, the mechanism that effectively creates inequality in the precivil condition, namely, the invention of money, is dependent on an extrajustificatory layer of consent. ${ }^{27}$ But this initial consent or agreement, even if ambiguously both "tacit and voluntary," includes the possibility that under

${ }^{25}$ Given the significance Locke placed upon the agreement to use money in the formation of political communities, his acknowledgment that "the Indians" in his time recognize silver as "the measure" of exchange supports Corcoran's claim about "Locke's resolute defense of the indefeasible native right to property and possession" (Paul Corcoran, "John Locke on Native Right, Colonial Possession, and the Concept of Vacuum domicilium," European Legacy 23, no. 3 [May 2018]: 226; and John Locke, Further Considerations concerning Raising the Value of Money, in The Clarendon Edition of the Works of John Locke: Locke on Money, vol. 2, ed. Patrick Kelly [Oxford: Oxford University Press, 1991], 423 [hereafter in notes and text FC followed by page number], although cf. II 184). For the opposing view that Locke's theory of property rights was devised, at least in part, to justify dispossession of indigenous peoples' lands, see David Armitage, "John Locke, Carolina, and the Two Treatises of Government," Political Theory 32, no. 5 (Oct. (2004): 602-27; Barbara Arneil, "Trade, Plantations and Property: John Locke and the Economic Defense of Colonialism," Journal of the History of Ideas 55, no. 4 (1994): 591-609; and Vicki Hsueh, "Unsettling Colonies: Locke, 'Atlantis' and the New World Knowledges," History of Political Thought 29, no. 2 (Summer (2008): 295-319.

${ }^{26}$ John Locke, Some Considerations of the Consequences of the Lowering of Interest and Raising the Value of Money, in Locke on Money, 1:250. Hereafter in notes and text SC followed by page number.

${ }^{27}$ Zuckert, Natural Rights, 270; Peter B. Josephson, The Great Art of Government: Locke's Use of Consent (Lawrence: University Press of Kansas, 2002), 188; and A. John Simmons, The Lockean Theory of Rights (Princeton: Princeton University Press, 1992), 302-3. 
conditions of civil government the normative meaning of money is transformed as it is assimilated into the comprehensive social compact that terminates the state of nature. Locke recognized the moral validity of pre- or extracivil economic exchange involving "promises and bargains for truck" between individuals in a nonmonetarized condition such as two people on a desert island or a "Swiss and an Indian, in the woods of America" (II 14). The natural law limits on acquisition apply in these situations precisely because these scenarios do not presuppose the existence of money.

Several commentators correctly identify the consensual origins of money in Locke's state of nature, but mistakenly deduce from this that Locke thereby placed consent to money in a "realm independent of politics." ${ }^{28}$ This conclusion neglects the important distinction underlying Locke's contract theory between the operation of consent under conditions of natural liberty and under those of civil liberty. The dyadic construction of consent allowed Locke to refine his argument in such a way as to render consent to money in the civil context capable of generating obligations to the social union insofar as the consent to use of money in civil society requires surrendering the natural liberty to use or not use money in exchange for the benefits provided by civil government. That is to say, exchange of money in the state of nature is directed by the natural law imperative of human preservation and thus, while not requiring a surrender of natural liberty per se, is nonetheless subject to the "inconveniences" of the state of nature that make economic activity unstable (II 13). In civil society, however, individuals surrender their natural liberty in exchange for government-provided benefits including a secure currency. ${ }^{29}$ Civil society transforms money by making possible an enhanced conception of trust that provides a normative grounding for Locke's largely utilitarian justification for inequality in the increased economic production made feasible by the invention of money. Locke's account of money in the Second Treatise exposes the psychological infrastructure of a monetized society dependent on the proper balance between the capacity of conventions to alter the "intrinsic" value of things and the need to generate sufficient trust among individuals to make a system of lending, borrowing, selling, and buying possible.

\section{The Natural Price of Money}

As we have seen so far, for Locke, money is in definitional terms both a physical substance and a mixed mode. It is both a quantifiable thing with certain

\footnotetext{
${ }^{28}$ Ince, “Accumulation in Locke," 36; Desan, Making Money, 350; and C. B. Macpherson, The Political Theory of Possessive Individualism (Oxford: Oxford University Press, 1962), 210.

${ }^{29}$ Somos identifies this distinction not as I do in the context of Locke, but rather in certain later American Revolutionary pamphlets. See Mark Somos, American States of Nature: The Origins of Independence, 1761-1775 (New York: Oxford University Press, 2019), 351.
} 
discernible characteristics and, at the same time, a mental construct representing a fundamentally moral determination of the value of something with respect to human needs. ${ }^{30}$ What, then, does "nature" mean in the context of Locke's treatment of interest rates, or as he puts it, "the natural price of money"?

Initially in Some Considerations, Locke presented what is natural as signifying the limits of legislative control inasmuch as he concludes it is "manifest" that the price of money cannot be "regulated by law." He applied the same question to inheritance and reached the identical conclusion: "it is impossible to make a law that shall hinder a man from giving away his money or estate on whom he pleases" (SC 211). This is a curious analogy, for in the First Treatise of Government Locke acknowledged that the natural right of inheritance is in fact typically regulated by "municipal laws" (I 91). What he appears to mean in the context of interest rates is, then, that the de facto rate of interest evades legislative control because "no man borrows money, or pays use, out of mere pleasure" (SC 211). Thus, given the necessitous character of lending and borrowing money, it will presumably not be easily discouraged by legal prohibition, if at all.

How, then, are we to make sense of Locke's claim that people only borrow money out of necessity, when he argued in the Second Treatise that the invention of money presupposed that individuals desire having "more than men needed" (II 37)? One possibility is that Locke intended to redefine necessity in terms of a relative or shifting standard of value such that money can change the intrinsic value of a thing only inasmuch as notions of what is useful for human life are not conceptually bound in essentialist or unchanging categories of the good. ${ }^{31}$ But did Locke believe that the idea of intrinsic or natural value had no substantive content whatsoever?

Locke approached this question through the concept of the "natural price" of money, which he defines as "the rate of money which the present scarcity of it makes it naturally at, upon an equal distribution of it" (SC 216). The "natural price" of money often militates against the policy of lowering interest rates because when the legal rate is too low, there is no real incentive to lend money: "For some years since, the scarcity of money having made it in England really worth more than [the official] six per cent" (SC 215). But if, as Locke claims, individuals borrow money out of necessity, then they will accept without objection loans at rates considerably higher than the artificially lower legal rate. Locke maintained that the natural price of money can be raised when the money supply is low in proportion to a country's

\footnotetext{
${ }^{30}$ Caffentzis, Clipped Coins, 75-76.

${ }^{31}$ But as Locke explained in his essay "Venditio," the natural value of a thing is not altered by changing its monetary price because a commodity now "will not feed more men nor better feed them than it did last year" at a different price. John Locke, "Venditio," in Locke: Political Essays, ed. Mark Goldie (Cambridge: Cambridge University Press, 1997 [1695]), 340.
} 
trade, so that if two million pounds were needed to carry on trade but only one million was actually available, then the natural price of money will be raised (SC 218). But the natural price of money is sui generis because money is a unique commodity that has a "double value" insofar as it serves both for exchange of goods and as a potential source of yearly income. In the latter case, there must be income inequality with some people having surplus money that they can lend at interest and others having less than they require to satisfy their needs (SC 250). Locke hereby draws a parallel between lending money and renting property-both of which depend on inequality - but he defends usury as being typically less exploitative then renting out land to tenants (SC 251).

Money is also a unique commodity because the normal market forces of supply and demand do not apply. For Locke, the pivotal concept relating to demand is "vent," by which he meant not simply demand, but rather a complicated relationship of commodities with variable consumption and elastic demand: "The vent is nothing else, but the passing of commodities from one owner to another in exchange... . This vent is regulated, i.e., made quicker or slower, as greater or lesser quantities of any saleable commodity are removed out of the way... and no longer lie within the reach of exchange" (SC 258-59). ${ }^{32}$ The concept of vent as it applies to money differs from other commodities insofar as the desire of money is consistently almost everywhere the same, and therefore "its vent varies very little, but as its greater scarcity enhances its price" (SC 255). The price of commodities naturally fluctuates, but demand for money will remain stable despite the quantity available. The quantity of money determines the price, but intrinsic value is determined by the amount of silver in weight and the price set to it on international exchanges. Intrinsic value, thus, does not mean unchanging worth, but rather "the value of money. . . depends only on the plenty, or scarcity of money, in proportion to the plenty and scarcity" of the necessaries and conveniences of life (SC 244). By this reasoning, the inflation in 1690s England compared to two centuries prior is due entirely to the increased supply of precious metals since European colonization of North and South America (SC 262-63).

Locke argues that lowering the legal rate of interest would actually decrease the money supply. It would be as if England hypothetically were suddenly to have only half as much money in circulation as it had seven years ago, and yet had the same annual product of commodities in which case "it is certain that either half our rents should not be paid, half our commodities not vented, or half our labourers not employed" (SC 266). Locke's commitment to a quantity-based theory of money meant that despite the vital role of labor in accounting for the origins of private property, he did

\footnotetext{
${ }^{32}$ See Vaughn, John Locke, Economist, 25-26, and Patrick Kelly, "'All Things Richly to Enjoy': Economics and Politics in Locke's Two Treatises of Government," Political Studies 36, no. 2 (June 1988): 279.
} 
not subscribe to a strict labor theory of exchange value. As Karen Iverson Vaughn describes Locke's economic theory: "labor creates value, but value is measured by the marketplace." ${ }^{33}$

The "intrinsic" value of money or any other commodity is not a deduction from a scientific law of nature. Rather it is "the universal consent of mankind" that has annexed value to silver and gold (SC 234). Insofar as Locke's theory of money presupposed a degree of naturalism, this extends only so far as there being actual specie or bullion to represent the "pledge, which writing cannot supply the place of" (SC 234). ${ }^{34}$ The "universal consent" expressed in the agreement to value gold and silver in exchangeable form across monetarized countries represents the "natural and current interest of money" in contrast to the "legal and forced" standard proposed by those who seek to lower the rate rashly through legislation (SC 253). Here "natural" and "current" mean what is widely accepted or freely, almost spontaneously, agreed to, whereas "legal" and "forced" suggest no general societal agreement upon value beyond a specific claim of legislative competence. The "natural price" of money is, then, a basis for generating the level of trust required for natural exchange and any system of credit and lending. Thus, Locke's use of "natural" in this context does not, as some commentators suggest, indicate his endorsement of a natural science of economics that transcends human volition. ${ }^{35}$ Rather Locke intended something closer to what Hugo Grotius identified as ius gentium or law of nations embodied in customary norms and laws based on a shared understanding of the value of silver and gold. ${ }^{36}$ It is this shared understanding that makes trust in exchange relations possible.

Far from signifying his putative commitment to proto-laissez-faire doctrine of the unregulated free market, ${ }^{37}$ Locke's main objection to lowering interest rates is his often ignored moral criticism of its distributive consequences as he highlights the injustice of punishing those "with estates in money" (whom he literally identifies as "widows and orphans"!), who are much more vulnerable to losses on the return of interest on their savings in money than the landed gentry (SC 219). However, this appeal to the plight of vulnerable people is balanced out somewhat by Locke's hardheaded assessment of how reduction in the money supply would affect the various socioeconomic classes in England. Laborers who typically live "from hand to mouth" (SC

${ }^{33}$ Vaughn, John Locke, Economist, 32.

${ }^{34}$ For Locke's concern about the unreliability of paper money at that time, see Dawson, Locke, Language, 288, and Caffentzis, Clipped Coins, 75-76.

${ }^{35}$ E.g., Letwin, Origins, 176; Vaughn, John Locke, Economist, 115; and Appleby, "Natural Law," 43.

${ }^{36}$ Hugo Grotius, The Rights of War and Peace, ed. Richard Tuck (Indianapolis, IN: Liberty Fund, 2005 [1625]), 1:162-63.

${ }^{37}$ This is in contrast to Appleby, "Natural Law," 44-45, and Edward Andrew, "Possessive Individualism and Locke's Doctrine on Taxation," The Good Society 21, no. 1 (2012): 155. 
236) would be the least affected because they have little cash on hand in any case. ${ }^{38}$ It is the landholders and brokers who will feel the greatest impact because the former are dependent on rents that will drop in price and the latter need to have considerable stores of surplus funds available to conduct business. In contrast to modern political economy, Locke did not consider consumers a distinct economic variable because "there are so few consumers, who are not either laborers, brokers, or landholders, that they make a very inconsiderable part in the account" (SC 242).

The most important normative dimension of Locke's analysis, however, has to do with the relation between the civil state and the monetary infrastructure undergirding the system of credit. Locke asserts that one of the "unavoidable consequences" of lowering interest rates will be to turn many thousands of English subjects into perjurers. If the reduction of coin in circulation will increase the natural price of money, then it is "likely to cause great perjury in the nation" as illegal borrowing is a crime involving "secret trusts and collusions of men" that can never be proved "without their confession." The problem of criminalizing perfectly rational and, in Locke's view, harmless behavior goes beyond the scope even of economic relations, for "faith and trust, especially in all occasions of attesting it, upon the solemn appeal to heaven by an oath, is the great bond of society." What is at issue, then, with respect to interest rates is nothing less than the moral preconditions of human sociability. Without public confidence in the veracity of oaths, witnesses, and pledges, "it will be impossible for the society... to subsist" (SC 213). While Locke believed establishing a healthy money supply is one of the basic purposes of civil government, he did not assume that the public good and private interest are simply identical. Lower interest rates may "be a gain to the borrowing merchant," but they do no good for the kingdom. Indeed, Locke saw an important role for government to promote distributive justice by protecting the people most vulnerable to the adverse effects of lowering rates, for "common charity teaches that those should be most taken care of by the law, who are least capable of taking care of themselves" (SC 220). Locke's technical arguments with respect to interest rates thus acquired moral significance in terms of the public authority entrusted with the task of securing the economic infrastructure of civil society.

\section{The Recoinage Controversy}

Further Considerations (1695), published at the height of the recoinage debate, commenced with an encapsulation of Locke's monetary theory: (1) "silver is

\footnotetext{
${ }^{38}$ Some commentators have taken these remarks to signify Locke's contempt for working-class people (e.g., Macpherson, Possessive Individualism, 216, and Gianna Englert, "Liberty and Industry: John Locke, John Stuart Mill, and the Economic Foundations of Political Membership," Polity 48, no. 4 [Oct. 2016]: 564). However, this criticism misses the normative thrust of his objections to a policy Locke takes to be injurious to the national economy as a whole.
} 
the instrument and measure of commerce in all the civilized and trading parts of the world," (2) "the intrinsic value of silver, considered as money, is that estimate which common consent has placed on it," and (3) "silver is the measure of commerce by its quantity, which is the measure also of its intrinsic value" (FC 410-11). By "intrinsic value," Locke typically meant the actual amount of silver in coins by weight, not the total amount of silver available in a given economy. However, in the context of the recoinage debate the concept of "intrinsic" takes an additional, even more primary, meaning for Locke as it signifies an economic version of the logical principle of noncontradiction foundational for speculative philosophy: "For an ounce of silver, whether pence, groats, or crown pieces . . . or in bullion, is, and always eternally will be, of equal value to any other ounce of silver" (SC 304-5). Thus, while the notional value of money may be determined by international markets, the substantive principle of value is not contingent on the market or exchange for "so much silver will always be worth . . . so much silver, given in exchange one another" (SC 318). The government thus cannot alter the actual value of silver, but may "only alter the denomination" of coins (SC 305).

The problem with the devaluation proposal advanced by Lowndes had to do with the difficulty relating to the semiotic capacity for mixed modes to be represented by substances. For example, minting shilling pieces one-twentieth weight lighter involves changing the denomination, not the value of silver. Locke concedes that "raising" one form of specie is manageable (if problematic) but devaluing all silver coin at once is potentially disastrous insofar as a general devaluation "will rob all creditors of one-twentieth of debts" (SC 309). The effect of this policy in Locke's view is to produce a form of grand larceny that reaches into the pockets of many English subjects. In contrast, Locke advised to restore all of the light, clipped coins to "full weight" through a demonetization process that is "orderly and by degrees" (FC 418). Moreover, he insisted that the recoinage process must involve a universal recall including not only clipped coins, but also all the "unclipped" full weight coins (FC 415).

Locke believed that only the complete reminting of all silver coins can ensure that they are no longer exported to be melted into bullion abroad (SC 334). The option of devaluing gold in order to disincentivize hoarding and clipping silver was not a viable policy because "gold is not the money of the world" as the agreement upon its use and exchange is not as "universal," comprehensive, and inclusive as silver (FC 423). Did Locke not see that recalling all silver coins would likely reduce the number of coins in circulation, and thus violate one of his own basic principles about the money supply? ${ }^{39}$ The answer is both yes and no. Locke expected that recoining would release the many full-weight coins from "Gresham's Hoard," that is,

${ }^{39}$ Douglas Vickers, Studies in the Theory of Money, 1690-1776 (Philadelphia: Chilton, 1959), 70-71, and Caffentzis, Clipped Coins, 33. 
bring them back into circulation, thus balancing out any potential reduction. ${ }^{40}$ However, on a more fundamental level, he was aware of the real possibility of diminishing the money supply, but concluded that there was a higher moral imperative to reaffirm the social agreement to the use of money.

The Second Treatise emphasized that the agreement to place value on a "yellow piece of metal" allowed the nonperishable, precious metals to represent quantities of perishable goods necessary for life (II 50). However, in his monetary tracts the semiotic question of representation focused specifically on the issue of coins. Why do we need coins at all, if the quantity of silver "makes the real value of it" (SC 311)? First, Locke acknowledged the practical inconvenience of requiring everyone to carry scales for every transaction. Coins thus do the service of signifying the quantity of precious metal. But this function does not resolve the basic question of what actually is being represented. Scales cannot distinguish between fine and mixed silver. Thus, the most important function of coins is to provide a publicly recognized measure of both the weight and the purity of the precious metal. This, of course, presupposed agreement upon the common guarantor of whom it may be said "the stamp was warranty of the public." Coin is metal transformed: "the public faith as security" (SC 312).

Locke reframed the technical questions surrounding the recoinage debate in distinctly normative terms, condemning coin clipping as a "robbery committed on the public" (SC 322). Thus, the moral effect of devaluation would be to validate an untold number of criminal acts. In contrast to Lowndes, Locke refused to countenance any compensation for holders of clipped coins owing to the fact that he believed they were complicit in this massive defrauding of the public inasmuch as they should have refused originally to accept these clipped coins in earlier transactions. ${ }^{41}$ The only beneficiaries of devaluation would be the bankers and brokers whose arbitrage Locke believed was largely responsible for the currency crisis in the first place. As the major possessors of full-weight coins hoarded up, there will, "by the proposed change of our money. . . be an increase of one fifth, added to their riches, paid out of the pockets of the rest of the nation" (FC 439). Locke was morally indignant at the prospect of what amounted to a speculator bailout that "will only serve to defraud the king, and a great number of his subjects" (FC 479).

Public authority was central to Locke's thinking about recoinage precisely because money is so indelibly woven into the moral foundations of civil society. For Locke, a monetarized economic system is both a series of social networks of trust and credit, and an agreement on the meaning of symbols and representational devices. ${ }^{42}$ The epistemic underpinnings of public

\footnotetext{
${ }^{40}$ Caffentzis, Clipped Coins, 36.

${ }^{41}$ J. Keith Horsefield, British Monetary Experiments, 1650-1710 (Cambridge, MA: Harvard University Press, 1960), 58.

${ }^{42}$ Craig Muldrew, The Economy of Obligation: The Culture of Credit and Social Relations in Early Modern England (New York: St. Martin's, 1998), 146-47.
} 
discourse apply as much to money as to other moral, ethical, and legal concerns, for "it is no wonder, if the price and value of things be confounded and uncertain, when the measure itself is lost" (FC 430). Civil government is meant to remedy the "inconveniences" of the state of nature (II 13) in which all too often individuals are "strangers or such as trust not one another" (FC 452). To Locke, restoring public confidence in the value of money required combating two corrosive effects of clipping. First, it meant recognizing that illicit clipping and legal devaluation both sanction important economic forces beyond the control of civil government. ${ }^{43}$ Locke feared that the precedent of devaluation in 1696 would potentially encourage further reckless devaluations in the future. By contrast, recoinage at the original weight and value would establish an important principle that the state will not cede control of the money supply to irregular and illegal market forces that "have taken off the authority of public stamp, and declared it not to be lawful money" (FC 414).

But perhaps an even more fundamental aim of Locke's plan for recoinage was to preserve the principle of the validity of contract. Lowndes's proposal for devaluation would reward a form of economic treason, and thus seems to condone the socially destructive idea that "men are absolved from performance of their legal contracts" (FC 415). Much as Locke's political theory was premised on the notion of free and equal individuals generating all of their civil obligations through consent, so too did he believe that the entire system of advanced economic exchange beyond the limited scope of natural barter depended on legally enforceable contractual obligations. If people could not trust the government to honor its promise about the value of coins, how could anyone trust the civil authority to enforce any other kind of contract? But Locke did not view the problem of devaluation solely in terms of violation of trust, for he also insisted that there was no evidence that it would achieve what its proponents sought to do, namely, bring more silver coins into circulation. Ultimately, Locke was convinced that both the principle of trust and the practical operation of commodity demand and supply would confirm his normative premise about money.

\section{Locke's Statecraft}

In the prior sections I have outlined an interpretation of Locke's economic tracts that follows Eich in reading politics back into his theory of money, but in what follows I will go even further to locate Locke's politics of money and trust in the context of his statecraft. Trust has long been viewed as a central feature of Locke's political and moral philosophy. ${ }^{44} \mathrm{I}$ have tried

${ }^{43}$ Caffentzis, Clipped Coins, 26.

${ }^{44}$ See, for example, John Dunn's important essay "Trust," in The History of Political Theory and Other Essays (Cambridge: Cambridge University Press, 1995), 91-99. 
to recontextualize Locke's treatment of money in terms of an account of trust that presupposed a considerable degree of confidence about the epistemic basis of political and social conventions as they interrelate with economic usages pertaining to the price of money or the value of silver. In his political writings, Locke argued that while the power of government is delegated from the natural executive power of individuals, the end for which government is entrusted with this power is solely "that men might have and secure their property" (II 11, 139). Locke identified "bounds" that this trust places on government action, which if taken "contrary to their trust" legitimizes the dissolution of power back to "the people [that] had put into their hands" this power in the first place (II 142, 221-22). But Locke insists that the revolutionary breakdown of trust is a relatively rare experience (II 224-26). He also located his treatment of money in the context of discourse about trust being the stabilizing "great bond of society" that makes a system of economic exchange possible (SC 213). But if trust in the institutional sense relates to a threshold with respect to assessing the violation or nonprotection of rights, how can money similarly be understood in terms of rights?

Locke's account of money reveals the vital economic dimension of his oftenneglected statecraft. ${ }^{45}$ In the Second Treatise, Locke alluded to "the great art of government" that produces "laws of liberty" designed to "secure protection and encouragement of honest industry" (II 42). Locke's argument with respect both to interest rates and recoinage established the priority of laws and policies designed to protect networks of credit. Locke presented the seventeenth-century English community very much in terms of a group of competing, but interdependent, households that need to trust one another. ${ }^{46}$ The maintenance of this system of trust is the primary object of Locke's statecraft, and the preconditions of trust are twofold: (1) preserving state control over the currency, and (2) upholding the principle of distributive justice.

The importance of state control over the currency is a function of the crucial role consent to the use of money plays in Locke's account of the social compact. While money originates in the state of nature, it is transformed by the public commitment to certain benefits derived from its use in civil society. As we have seen, clipping coins undermines this public commitment as it amounts to "raising it [the value of a denomination] without public authority" (FC 417) and is in effect "robbery committed to the public" (SC 322). Locke's statecraft is, then, directed in part to remedying deleterious economic forces that originate beyond the control of civil government. ${ }^{47}$ In this sense, Locke's desire to restore systemic balance in the economy by reaffirming the legally established connection between silver content and specific

\footnotetext{
${ }^{45}$ An important exception to this tendency to ignore Locke's statecraft is Josephson, Great Art of Government.

${ }^{46}$ Muldrew, Economy of Obligation, 124.

${ }^{47}$ Caffentzis, Clipped Coins, 26.
} 
denominations parallels his call in the Second Treatise for the exercise of prerogative power to restore a "fair and equal" system of representation in a legislature that has become "very unequal and disproportionate" as a result of gradual demographic changes (II 157-58). ${ }^{48}$ In both cases, Locke's aim was to reaffirm the fundamental principle of consent underlying the political community. Similarly, much as a corrupt legislature cannot be expected to reform itself, so too Locke suggests that the civil state's role in securing legal currency is irreplaceable as is obvious from the inability of individuals qua individuals, or even as members of civil society, to solve the problem of coin clipping without government intervention. ${ }^{49}$ But is this an exercise of practical reason and statecraft or merely a demonstration of what Eich identifies as an attempt to restore in a mechanistic manner the conditions of the original monetary agreement?

While clearly revealing an important political aspect of Locke's view of the origins of the monetary compact, Eich's emphasis on fiat also disconnects money from Locke's statecraft by highlighting what Eich takes to be the arbitrary and rigid character of Locke's judgment about money, rather than the prudential dimensions I identify. I resituate Locke's monetary compact in terms of a modulation in his theory of consent, which is capable of being formative, legitimating and even constitutive, but does not assume the supraobligatory status Locke ascribed to the creation of a "People" (II 89, 120, 222). Thus, while Locke may have sought to delegitimize certain kinds of discretionary political meddling in the currency, his statecraft presupposed that decisions about the range of matters that are exclusively beyond the normal political process are themselves subject to deliberation and revision. This is not to suggest that Locke would have rejected the idea of central bank independence, although he was famously rather ambivalent about the fledgling Bank of England. And it is certainly true that a "sound money" policy could be a prudential exhortation about the dangers of devaluation. However, the problem with associating Locke with a philosophical commitment to sacrosanct currency is that this, for all practical purposes, dissolves prudence, and as history seems to confirm, tends to validate the incorporation of Locke's theory of money into a strict, quasi-scientific monetary doctrine antagonistic to statecraft.

Clearly, Locke viewed recoinage in terms somewhat prohibitive with respect to government action, arguing that "the quantity of silver established under the several denominations... should not be altered till there was an absolute necessity shown of such a change, which I think can never be" (FC 415), and that once the standard metallic alloy of coins has been settled, it "should be inviolably and immutably kept to perpetuity" (SC 329). While these passages suggest that he sought in some sense to depoliticize money,

\footnotetext{
${ }^{48}$ See Casson, Judgment, 245.

${ }^{49}$ Emily C. Nacol, An Age of Risk: Politics and Economy in Early Modern Britain (Princeton: Princeton University Press, 2016), 67.
} 
it is important to distinguish between the uncompromising rhetoric of Locke's polemic and the decidedly utilitarian logic of his argument. First, despite his protestations of horror about the prospect of devaluation, Locke was well aware of the past practice of currency revaluations in England and elsewhere (FC 458-60). He even conceded that many English people had tacitly consented to a de facto devaluation of silver coin by factoring in the added cost of lighter coins into their exchanges, borrowing, and debts (FC 469). Moreover, as Richard Kleer demonstrates, Locke was aware that the purchasing power of English coin could change over time independently of its metallic content, for "there is no manner of settled proportion between the value of an ounce of silver, and any other commodity." 50 Clearly, then, Locke recognized that his call for recoinage at original value was not the universal practice.

More importantly, Locke framed the issue of the epistemic stability of money within the context of his doctrine of the public good, which presupposed the value of prudential judgment. An unalterable monetary standard is not an axiom insofar as it is necessarily conditioned by the fundamental principle of the public good salus populi suprema lex (the safety of the people is the highest law) (II 158). The decisive problem with devaluation is the foreseeable consequences, for "the public will lose by it" (SC 329). Locke's presumption is that "under the present denomination," England has "had a greater increase, and larger continuance of plenty of money, than perhaps any other country can show" (FC 463). Thus, the metallic content of the denominations should not be altered unless there is an "absolute necessity" for change (FC 415). But it is a matter of practical reason to decide whether this absolute necessity has arisen. One measure of this necessity can be seen in Locke's judgment that in England devaluation would injure creditors "without any the least advantage to the public" (FC 416). It is likely that he did in fact see some advantages to Lowndes's devaluation scheme, ${ }^{51}$ but he decided that on balance it was more important to reassert state control over the currency and to deter future coin clipping. Arguably, then, Locke's polemical strategy was to combat Lowndes's plausible proposal by exaggerating the certainty of his own argument about the stability of the monetary standard.

Locke's argument is animated in part by the particular context of the unique historical conditions that made his recoinage plan dependent on the improved milling techniques that promised to dramatically reduce clipping in the future. In the absence of improved milling techniques, would Lowndes's proposal have been more consistent with Locke's aim of restoring public trust in the money supply? Arguably this contingent fact would have made a considerable difference to Locke's calculations. Moreover, the specific conditions produced by extralegal actions such as clipping and international arbitrage require that it was in the long-term interest to restore public

\footnotetext{
${ }^{50}$ Kleer, "'Ruin of Their Diana,'” 544.

${ }^{51}$ Carey, "Philosophy of Money," 70.
} 
confidence in the legal currency because failure to do so would "destroy the public faith" in future acts of Parliament relating to aspects of the economy beyond currency including loans, public debt, and banking (FC 417). Locke's public good imperative does not, then, foreclose the possibility that devaluation could be an apposite action in a different context, even if he presumes that in 1690s England such a policy would be seriously mistaken.

As we have seen, Locke's conception of trust in his monetary tracts also presupposed an underlying principle of distributive justice. Locke recognized that as a procedural and historical question, it was clearly within Parliament's purview both to set and to change currency denominations (FC 458-60). However, the political judgment about the substantive impact of government action would fall within the prudential orbit of Locke's thoughts on the distributive consequences of monetary policy. While most modern commentators tend to ignore considerations of distributive justice in favor of focusing on his putative fixation on the unalterable metallic content of coins, for Locke and his contemporaries the question of who will bear the costs of devaluation was of equal or even more importance. ${ }^{52}$ The fundamental assumption underlying Locke's account of the distributive consequences of devaluation was that all legal contracts are executed in silver by weight, not by denomination. Several implications flowed from this premise. First, he insisted that currency devaluation would "rob all creditors of onetwentieth (or 5 per cent) of their debt" (SC 309). But Locke was not simply defending the interests of the investor class that would become central to the Financial Revolution in England. As we have noted, he worried also about the impact of monetary policy on people surviving on relatively fixed incomes (SC 219). Locke feared that devaluation in England would only reward the speculators "who have great sums of weight money. . . hoarded up by them" by increasing their income by one-fifth "paid out of the pockets of the rest of the nation" (FC 439). The great social danger in lowering interest rates would be to centralize economic control in the hands of bankers and goldsmiths (SC 216), even as he warned that this concentration of financial power would come at the expense of institutions such as "the Church, the Universities and Hospitals" that would be injured by devaluation (FC 417). ${ }^{53}$ Thus, for Locke, the distributive consequences of monetary policy

\footnotetext{
${ }^{52}$ For example, distributive justice is either not a consideration or is dismissed completely in the treatment of Locke's position in the coinage debate that we see in Eich, "Depoliticization"; Kelly, introduction to Locke on Money; Li, Great Recoinage; and Desan, Making Money, 358. Kleer, "'Ruin of Their Diana,'" 545-56, does recognize the distributive justice dimension of Locke's argument, but he views these questions more as a matter of partisan conflicts within the Whig establishment than as a function of Locke's political philosophy per se.

${ }^{53}$ For Locke's distrust toward the banks, see Kelly, introduction to Locke on Money, 26, and Steven Pincus, 1688: The First Modern Revolution (New Haven, CT: Yale University Press, 2009), 46.
} 
required consideration about not only the potential impact on the poorer classes, but also about the negative effects of cartelism and speculation on England's system of credit and civil society more broadly.

From Locke's perspective, Lowndes's devaluation plan fails to protect rights because it does not take into account "equity and consideration of the subjects' property" (FC 457). It placed an unfair burden on ordinary people and those whom "common charity" teaches should most be provided for in law (SC 220), while rewarding the speculators who were most responsible for the currency crisis in the first place. Locke insisted that the interests of private individuals cannot be sacrificed with the "least advantage to the public" (FC 416). Salus populi suprema lex requires that while Locke was committed to the individual right of self-preservation, he was also, as Peter Josephson describes, a political realist who incorporated the political community's "native and original right" to preserve itself into his consideration about justice (II 220). ${ }^{54}$ "A gain to the borrowing merchant" may not be good for the public (SC 220). Locke did not simply assume that there was no conceivable context in which injury to one group could be justified in terms of the "advantage to the public." Rather these judgments about the subjects' property would require prudential judgment suited to a regime committed to individual natural rights.

\section{Conclusion}

On January 2, 1696, Parliament passed the Act for Remedying the Ill State of the Coin based in large part on Locke's recommendation. Commentators are practically unanimous in their judgment that Locke's economic policy advice was mistaken, Lowndes's devaluation plan was correct, and the implementation of Locke's recoinage plan had a disastrous effect on England's economy as it produced an easily foreseeable dramatic reduction in the money supply in circulation with an even more predictable deflationary impact. ${ }^{55}$ It is hard, then, to escape the conclusion that Locke's argument against currency devaluation was a remarkable misfire. However, simply dismissing Locke's foray into economic policymaking and ordering his legacy back to a contemplative ivory tower would be a serious error. To start, we need to account for the historical fact that Locke's basic argument against devaluation would be taken by many for centuries as the philosophical inspiration for the gold standard,

\footnotetext{
${ }^{54}$ Peter B. Josephson, “Hobbes, Locke and the Problems of Political Economy," in Economic Freedom and Human Flourishing: Perspectives from Political Philosophy, ed. Michael R. Strain and Stan A. Veuger (Washington, DC: American Enterprise Institute, 2016), 19.

${ }^{55}$ Appleby, "Natural Law," 56; Kelly, introduction to Locke on Money, 64-65; Horsefield, Monetary Experiments, 36; Casson, Judgment, 253; John Chown, A History of Money (New York: Routledge, 1994), 63; and Joseph Schumpeter, A History of Economic Analysis (New York: Oxford University Press, 1954), 285.
} 
even though the putative father of "sound money" expressed some ambivalence about the polemical nature of the monetary tracts, later citing them as works that "are not those which I now relish, or that do, with Pleasure, employ my thoughts." 56

More importantly, however, Locke's monetary tracts reveal a dimension of his moral philosophy that is perhaps only partly visible in his more familiar political writings. Locke has been accused of advancing abstract theories of right at the expense of all but ignoring the practical art of governance. ${ }^{57}$ Admittedly, in the Second Treatise Locke made only vague, but suggestive, reference to the "great art of government" that complements his natural rights philosophy. But while a full account of the priorities of this "great art of government" is somewhat elusive in Locke's corpus, the identification of its end as encouraging "honest industry" arguably highlights the centrality for political life of the issues, both economic and normative, that were the focus of his pamphlets on money. As Desan observes, the pattern set by Locke's emphasis on the fiduciary role of government regarding currency later helped to legitimate bank money and new credit instruments. ${ }^{58}$ Locke's writings on money serve a significant role, then, not only in situating the economic dimension of his teaching on trust, but also in limning the features of a conception of distributive justice in civil society that is compatible with the idea of government devoted to the protection of individual rights. Arguably it is only by way of integrating Locke's economic writings into his broader political philosophy that we can appreciate the full range of theoretical perspectives and practical possibilities for political involvement in the economy offered by Locke's statecraft.

\footnotetext{
${ }^{56}$ Locke, 1696 letter to William Molyneux, cited in Li, Recoinage, 104-5.

${ }^{57}$ J. G. A. Pocock, "A Discourse on Sovereignty," in Political Discourse in Early Modern Britain, ed. Nicholas Phillipson and Quentin Skinner (Cambridge: Cambridge University Press, 1993), 394.

${ }^{58}$ Desan, Making Money, 360-61.
} 